\title{
Histidine Decarboxylase
}

National Cancer Institute

\section{Source}

National Cancer Institute. Histidine Decarboxylase. NCI Thesaurus. Code C90138.

Histidine decarboxylase ( $662 \mathrm{aa}, \sim 74 \mathrm{kDa}$ ) is encoded by the human HDC gene. This protein plays a role in the biosynthesis of histamine from histidine. 